\title{
Raw Images
}

Fig. 18:

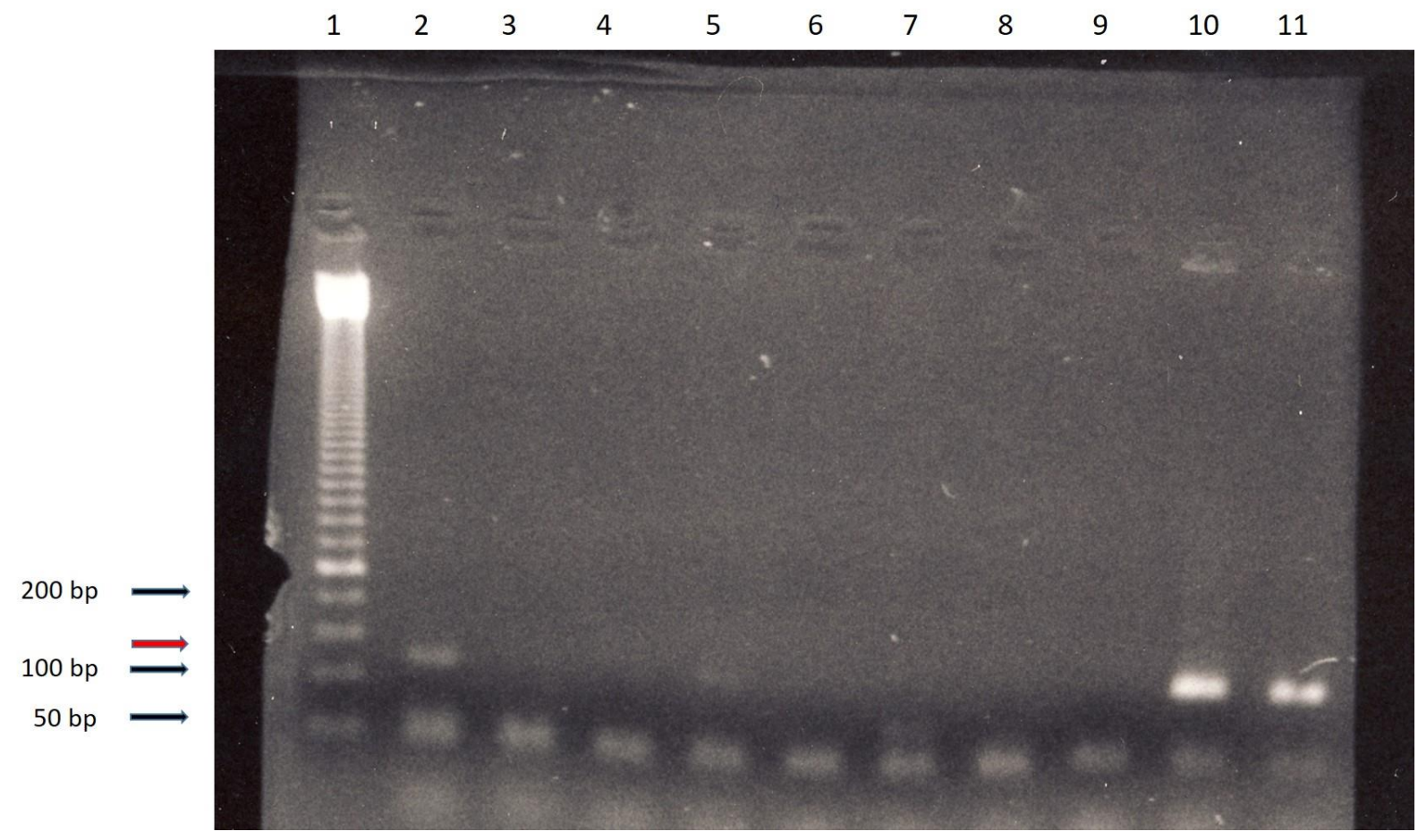

Fig. 19:

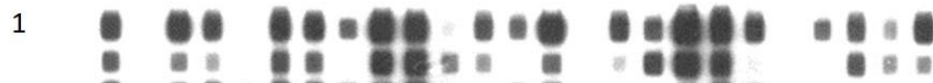

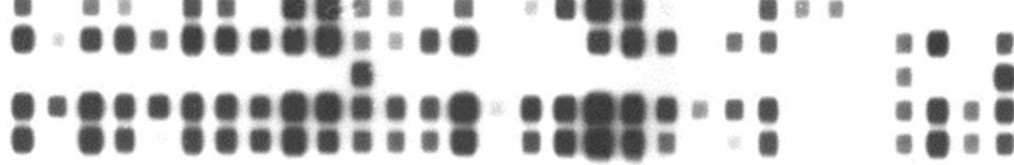

1. 둔.

\section{ma!m!n}

-

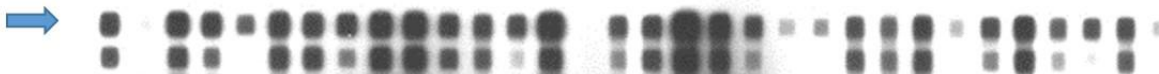
- -

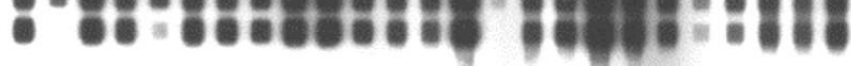

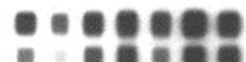
8ำㄷำ

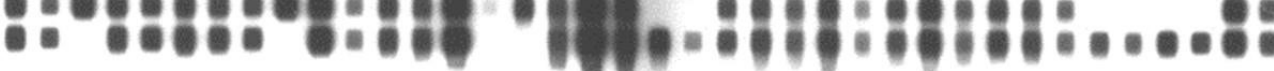

